\title{
Kyphoplasty in osteoporotic vertebral compression fractures - Guidelines and technical considerations
}

\author{
Yohan Robinson ${ }^{1 *}$, Christoph E Heyde ${ }^{2}$, Peter Försth ${ }^{1}$ and Claes Olerud ${ }^{1}$
}

\begin{abstract}
Osteoporotic vertebral compression fractures are a menace to the elderly generation causing diminished quality of life due to pain and deformity. At first, conservative treatment still is the method of choice. In case of resulting deformity, sintering and persistent pain vertebral cement augmentation techniques today are widely used. Open correction of resulting deformity by different types of osteotomies addresses sagittal balance, but has comparably high morbidity.

Besides conventional vertebral cement augmentation techniques balloon kyphoplasty has become a popular tool to address painful thoracic and lumbar compression fractures. It showed improved pain reduction and lower complication rates compared to standard vertebroplasty. Interestingly the results of two placebo-controlled vertebroplasty studies question the value of cement augmentation, if compared to a sham operation. Even though there exists now favourable data for kyphoplasty from one randomised controlled trial, the absence of a sham group leaves the placebo effect unaddressed. Technically kyphoplasty can be performed with a transpedicular or extrapedicular access. Polymethyl methacrylate (PMMA)-cement should be favoured, since calcium phosphate cement showed inferior biomechanical properties and less effect on pain reduction especially in less stable burst fractures. Common complications of kyphoplasty are cement leakage and adjacent segment fractures. Rare complications are toxic PMMA-monomer reactions, cement embolisation, and infection.
\end{abstract}

Keywords: Kyphoplasty, vertebroplasty, osteoporosis, spinal fractures

\section{Introduction}

Osteoporosis and pathological osteoporotic fractures are common findings in the elderly population. The agestandardised annual incidence of vertebral compression fractures (VCF) is 10.7/1000 in women and 5.7/1000 in men, increasing markedly with age [1]. At the age of 75 to 79 the annual incidence was $29.3 / 1000$ in women and $13.6 / 1000$ in men. Due to the continued aging of our population, VCF represent a major cause of disability and are a burden to the national healthcare budgets [2]. Non-surgical management with pain control and physical therapy-assisted mobilization has for a long time been the only treatment option in VCF. Unfortunatelty a great number of patients remain functionally impaired

\footnotetext{
* Correspondence: yohan.robinson@surgsci.uu.se

'Uppsala University Hospital, Institute for Surgical Sciences, Department of

Orthopaedics, Uppsala, Sweden

Full list of author information is available at the end of the article
}

after VCF, and some of them are severely handicapped due to chronic back pain [3]. The functional and physical consequences of VCF lead to anxiety, depression, and have devastating impact on interpersonal relationships and social roles [4]. It is therefore no surprise that untreated VCF contribute significantly to shorter lifeexpectancy both in women (mortality ratio 1.66, p < 0.01 ) and even greater in men (mortality ratio 2.38, p < 0.0001 ) within one year after onset of symptoms [5].

\section{Indications for cement augmentation}

while medical therapy of osteoporosis improves dramatically, the restoration of quality of life is still a major issue in VCF treatment. Osteoporotic kyphotic compression fractures often lead to a anterior shift of the sagittal plumb line and increased load of the anterior vertebral column, which may cause further compression fractures [6]. This cascade of sequential compression fractures is
Ciomed Central

(c) 2011 Robinson et al; licensee BioMed Central Ltd. This is an Open Access article distributed under the terms of the Creative Commons Attribution License (http://creativecommons.org/licenses/by/2.0), which permits unrestricted use, distribution, and reproduction in any medium, provided the original work is properly cited. 
eventually causing the typical hump of the elderly, with significant thoracic kyphosis and low pelvic incidence, forcing the patient to bend hips and knees to maintain sagittal balance [7].

Galibert et al [8] presented the first cases of successful vertebral augmentation by intravertebral injection (vertebroplasty) of polymethyl methacrylate (PMMA) in patients with vertebral haemagiomas. Later, vertebroplasty was successfully introduced for the management of osteoporotic compression fractures [9]. The primary goal of vertebroplasty is pain relief by stabilization of the VCF, improving indirectly pulmonary function and patient quality of life [10]. The biomechanical understanding of increasing anterior column load with progressing kyphosis leading to subsequent VCF established the basic rationale for kyphoplasty. With this technique, partial reduction of VCF is possible by transpedicular intracorporal balloon expansion and retention by PMMA cement augmentation [11,12]. The results of one multicenter randomised controlled trial found shortened and improved functional recovery after kyphoplasty with a low rate of complications if compared to non-surgical treatment [13].

Despite the advances in percutaneous augmentation techniques the conservative medical therapy cannot be replaced. VCF without initial kyphosis, no consecutive sintering and a satisfactory and quick response to conservative treatment should be treated conservatively. Furthermore, since lack of reimbursement in most countries kyphoplasty causes an economic burden, many patients are not willing to take. Beyond that, it has to me emphasised, that it remains unclear whether the benefits of kyphoplasty outweigh its complications.

Two placebo-controlled vertebroplasty-studies have sobering results with regard to pain and functional outcome after cement augmentation with vertebroplasty, if compared to a sham-operation $[14,15]$. In both studies the sham procedure included percutaneus needle insertion and opening of PMMA-monomer mixture to simulate the specific odour. The sham-controlled trial by Buchbinder et al [14] in 78 patients with MRI-confirmed, fresh and painful VCF found no beneficial effect of vertebroplasty when compared to a sham procedure.
A very similar study by Kallmes et al [15] investigating 131 patients found similar results. This study had already after 3 month significant higher cross-over of $43 \%$ in the control-group ( $\mathrm{p}<0.001$ ) diminishing the quality of this study. Furthermore only outpatients were included in this study, which means that no patients being hospitalised due to acute VCF entered the study. The randomised controlled trial by Rousing et al [16] found no greater improvement in back pain in patients treated with vertebroplasty when compared to medical therapy. Interestingly they found a significant improvement in the Barthel-score after 12 month $(\mathrm{p}<0.02)$ indicating improved function, [17]. As a result to the above-mentioned results several authors abandoned the use of vertebroplasty [18-20] while others are hesitant and question the quality of the sham-controlled vertebroplasty trials $[17,21]$. It is unclear whether the results of the multicenter randomised kyphoplasty trial could be reproduced if sham-controlled [13]. In table 1 the authors present clinically proven guidelines for indications and contraindications of kyphoplasty.

Due to the increased demand in cement augmentation techniques, procedures similar to kyphoplasty have been developed. One competitor is Vesselplasty ${ }^{\circledR}$ (A-Spine), where a porous balloon is inflated within the fractured vertebral body and filled with cement without removing the balloon, thus reducing the risk of cement leakage [22]. Another new product is the Sky ${ }^{\mathbb{B}}$ bone expander (Disc-O-Tech), an expandable polymer bone tamp abandoning the use of cement, which had favourable results in clinical case series [23]. Then there is the $\operatorname{StaXx}{ }^{\mathbb{B}}$ FX system (Spine Wave) where a VCF is reduced percutaneously by gradual insertion of stacked PEEK-chips into the vertebral body to reduce and stabilise the fracture [24].

\section{Indications for combined cement augmentation and posterior instrumentation}

Lately kyphoplasty has been discussed as an alternative therapy even of burst fractures in elderly patients. This is especially true in case of AO type A3.1 fractures, where it could be applied instead of a posterior-only or 360 degrees stabilisation [25]. In many of these

Table 1 Guidelines for indications and contraindications for kyphoplasty

\begin{tabular}{|c|c|}
\hline \multirow[t]{2}{*}{$\begin{array}{l}\text { Indications for } \\
\text { kyphoplasty }\end{array}$} & $\begin{array}{l}\text { - Radiologically confirmed fresh compression fracture (AO type A1) (MRI shows oedema or X-ray/CT-scan } \\
\text { proven fracture not older than } 3 \text { months) }\end{array}$ \\
\hline & $\begin{array}{l}\text { - Failure of } \mathbf{2} \text { - } \mathbf{6} \text { weeks of conservative treatment including pain medication and physiotherapy (Pain on } \\
\text { visual analogous scale (VAS) above } 4 \text { of 10) }\end{array}$ \\
\hline \multicolumn{2}{|l|}{ Contraindications for } \\
\hline \multirow[t]{4}{*}{ kyphoplasty } & - Burst-fractures (in some A3.1-fractures possible) \\
\hline & - Flexion-/distraction and rotational injuries ( $\mathrm{AO}$ type $\mathrm{B}$ and $\mathrm{C}$ ) \\
\hline & - Medical contraindications (bleeding disorders, sepsis, etc) \\
\hline & - PMMA-allergy \\
\hline
\end{tabular}


cases further sintering of the fractured vertebra with posterior dislocation of an instable fragment with spinal stenosis is a feared complication [26,27]. Thus several surgeons perform posterior instrumentation of the adjacent vertebrae to protect the posterior wall and to improve the sagittal profile [28]. This can be done using percutaneous posterior instrumentation or with a conventional open technique [28-30]. Possible disadvantages of this technique are due to segmental fusion an increased load of the adjacent segments with degeneration, and possible implant loosening with loss of correction due to low bone quality. Cement augmentation of the implanted pedicle screws can reduce the complication rate regarding the latter mentioned problem [31].

\section{Limitations of kyphoplasty and indications for open reduction and stabilisation}

If multiple VCF lead to kyphosis with fixed sagittal imbalance, cement augmentation will address the fracture pain but not global imbalance. Major spinal imbalance can be a cause of significant functional disability leading to reduced quality of life. Increased kyphosis may additionally cause subsequent VCF due to an increased anterior load [32]. The anterior location of the sagittal plumb line in fixed sagittal imbalance will lead to falls with possible further fractures and morbidity. Therefore the indication for correction of global sagittal imbalance may be given in severe cases. As both open and closing wedge procedures are associated with complications leading to disabling morbidity surgeon are often hesitant to perform these operations in patients with multiple comorbidities [33]. Due to the osteopenic bone quality often long instrumentations are required.
Unfortunately these an increased risk of adjacent VCF and pedicle fractures [34]. With regard to open sagittal corrections there is growing evidence that the posterioronly pedicle subtraction osteotomy is superior to multiple Smith-Petersen osteotomies, allowing greater correction with lesser operation time $[35,36]$.

\section{Operation technique of kyphoplasty}

\section{Percutaneous bilateral transpedicular kyphoplasty}

The bilateral transpedicular approach is the standard kyphoplasty access for the thoracolumbar spine, enabling a symmetric reposition and augmentation of the VCF. Firstly, the fracture is reduced under fluoroscopic control by positioning and traction. Then biopsy needles are used to enter the fractured vertebra on both sides through the pedicle (figure 1). If fluoroscopy confirms correct transpedicular placement of the needles in both planes, a K-wire is placed through the Jamshidi biopsy needle into the vertebral body close to the anterior wall. Then over the K-wire the access is widened with the osteointroducer. Then empty bone-fillers are used to form a cavity for the safe placement of the balloons. Under fluoroscopic control two balloons are positioned anteriorly within the vertebral body, and then the balloons are inflated under manometric control. In fresh fractures up to 150 psi balloon pressure are mostly enough, but sometimes up to 300 psi are necessary to reduce a partially healed compression fracture. One has to be careful not to fracture the endplates or the posterior wall, which could lead to cement leakage. After successful reduction the cavity is filled with bone-cement from both pedicles. This step has to be performed with careful fluoroscopic control. Normally the cement should have a tooth-paste-like viscosity and should not
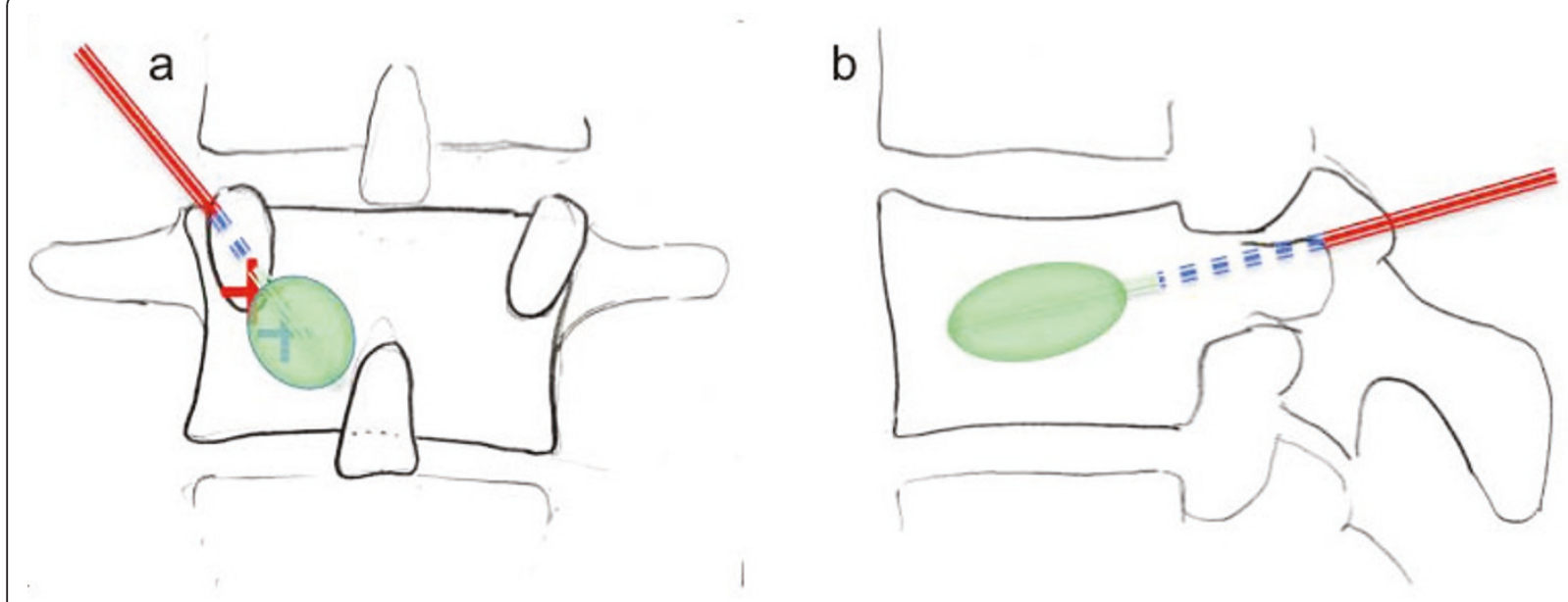

Figure 1 Transpedicular approach for balloon kyphoplasty. After entry in the craniolateral pedicle (red cross) in the p-a-projection (a), the medial cortex of the pedicle is first breached when the vertebral body is entered in the lateral projection (blue cross) (b). After preparation of the working channel a balloon can be placed in the vertebral body. 
stick to the surgeons' gloves when testing the viscosity. Finally the introducers are removed.

\section{Percutaneous unilateral extrapedicular kyphoplasty}

Due to the anatomical characteristics of the thoracic spine central placement of the balloons can be difficult. Firstly, the introducer often does not fit in the narrow pedicles of the thoracic spine. Then the low angulation of the pedicles does not allow a central placement of the balloons disabling adequate reduction in some cases. Thus in the thoracic spine extrapedicular accesses gain increasing popularity, avoiding pedicle perforation with possible neurological damage or intraspinal cement leakage. Most surgeon prefer the transcostovertebral access from far lateral (figure 2), guided to the collum costae into the costotransversary space to the cranio-posterior wall of the fractured vertebra, the Jamshidi needle with the tip just penetrating the lateral pedicle at its base $[37,38]$. In the view from posterior the needle passes above of the transverse process and meets the pedicle at the craniolateral circumference. The lateral view confirms the placement of the tip of the needle close to the base of the pedicle. In an axial view the needle is seen to pass through the costovertebral gap, between the neck of the rib and the lateral pedicle circumference, towards the base of the pedicle. Then the posterolateral cortical wall is opened with a Jamshidi cannula and widened as described above with $\mathrm{K}$-wire and osteointroducer. To allow central placement of the balloon in the vertebral body a greater angle than in the transpedicular placement has to be sought. This often requires a 7 to $10 \mathrm{~cm}$ off-midline percutaneus approach. A single balloon is then used for reduction and the cavity is then filled with cement as described above.

\section{Open unilateral interlaminary kyphoplasty}

Open interlaminary kyphoplasty should be reserved for cases where an open approach has to be performed to decompress neurological structures, and the spinal canal has to be accessed anyway [39]. After open decompression the dural sac is retracted medially and the posterior wall of the fractured vertebra exposed. Now kyphoplasty can be performed with a single balloon positioned under fluoroscopical guidance in the centre of the vertebral body. After kyphoplasty the spinal canal has to be investigated for cement leakage. This method must be restricted to levels below the conus medullaris to avoid myelopathy due to manipulation within the spinal canal.

\section{Open anterior kyphoplasty}

In rare cases kyphoplasty may be performed using an anterior access, too [40]. Through a minimally-invasive anterior access the biopsy needle may be placed directly on the anterior wall of the fractured vertebra and a single balloon be placed into the vertebral body. Then under fluoroscopical control the fracture is reduced and cement is applied.

\section{Technical considerations \\ Operation room setup}

Both general an local anesthesia have been successfully applied for the procedure [41], but many surgeons favour general anestesia allowing closed reduction in a relaxed patient. By patient positioning only, more than $70 \%$ of vertebral height restoration can be achieved. Placing the patient in prone position lordosating the fractured segment by pillows or by bending the table will lead to reduction of the fracture with ligamentotaxis [42].

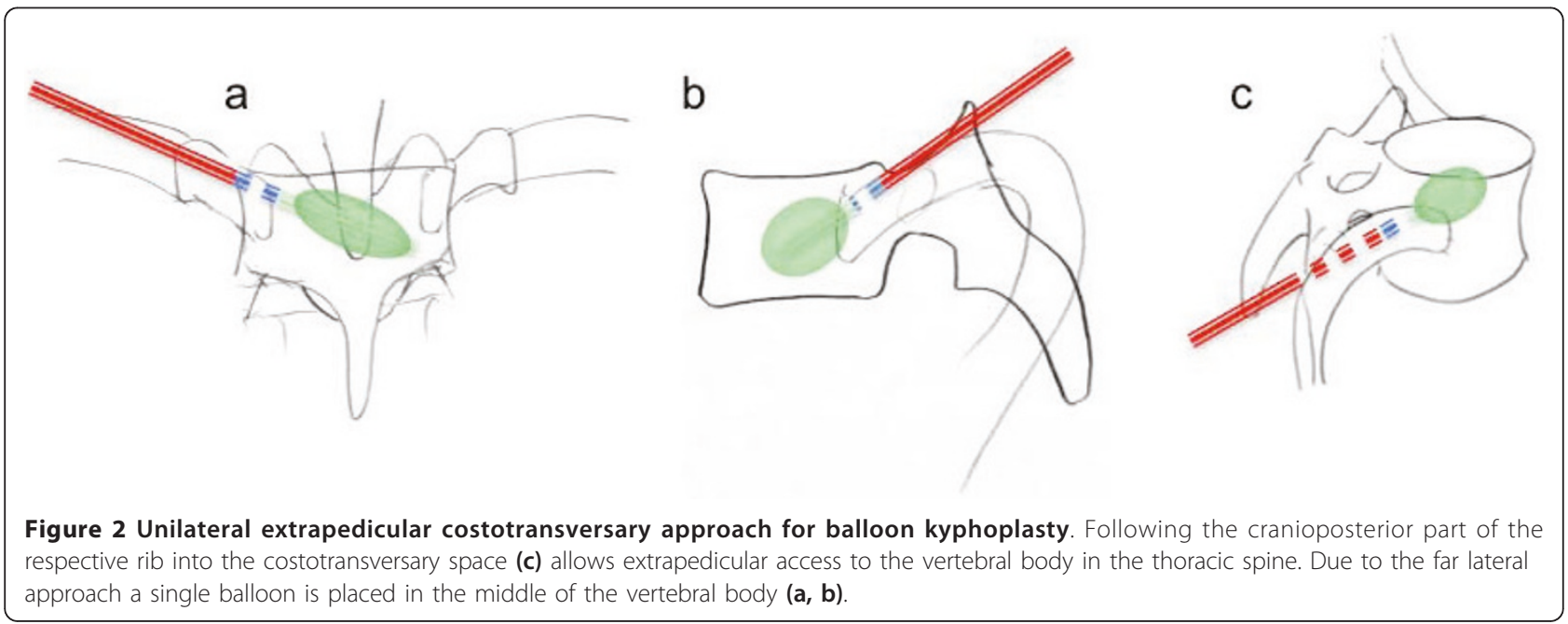


As in most percutaneus surgical techniques implant positioning and accuracy is controlled with fluoroscopic image intensifiers. Correct positioning of the image intensifier will lead to much lesser radiation dose for the surgeon. Placement of $x$-ray tube in the image intensifier on the opposite side of the surgeon will causes up to 10 times less radiation exposure [43].

\section{Navigation}

Balloon placement accuracy can be significantly improved and the radiation exposure during kyphoplasty can be reduced by as much as $76 \%$, if computer-assisted fluoroscopic navigation is applied [44,45]. While relying on the navigator during the transpedicular balloon placement, balloon inflation and cement injection have to be performed under fluoroscopic control to minimise endplate fractures and cement leakage.

\section{Eggshell procedure}

An eggshell-procedure may avoid cement leakage in VCF suscpicious for endplate or posterior wall damage [46]. After reduction with the kyphoplasty balloon a small amount of doughy cement is injected into the cavity, and then the balloon reinserted and reinflated. Once the cement hardens the cavity can be filled with cement within the "eggshell", preventing cement leakage.

\section{Choice of cement}

Most vertebroplasty and kyphoplasty procedures have been performed using polymethylmethacrylate (PMMA) cement to augment the fractured vertebra. The increasing availability of injectable calcium phosphate $(\mathrm{CaP})$ cement led to its application in the augmentation of compression fractures as an alternative to PMMA. Advantages are high biocompatibility, no

Table 2 Overview on comparative clinical trials of kyphoplasty

\begin{tabular}{|c|c|c|c|c|c|c|c|c|}
\hline Author & Year & Design & $\begin{array}{l}\text { Level of } \\
\text { evidence }\end{array}$ & $\begin{array}{l}\text { Control } \\
\text { Group }\end{array}$ & $\begin{array}{l}\text { Control } \\
\text { n } \\
\text { (levels) }\end{array}$ & $\begin{array}{l}\text { Kyphoplasty } \\
\text { n (levels) }\end{array}$ & $\begin{array}{l}\text { Follow- } \\
\text { up }\end{array}$ & Outcome \\
\hline $\begin{array}{l}\text { Weisskopf et } \\
\text { al. [54] }\end{array}$ & 2003 & Retrospective & $\| l \mathrm{~b}$ & non-surgical & $20(35)$ & $22(37)$ & 10 days & $\begin{array}{l}\text { Improvement in VAS }(p<0.001) \text { Reduced days } \\
\text { in hospital }(p<0.01)\end{array}$ \\
\hline $\begin{array}{l}\text { Fourney et } \\
\text { al. [55] }\end{array}$ & 2003 & Retrrospective & Illb & vertebroplasty & $34(65)$ & $15(32)$ & $\begin{array}{l}4,5 \\
\text { months }\end{array}$ & $\begin{array}{l}\text { No significant differences in VAS and ODI } \\
\text { Improvement of kyphosis with kyphoplasty } \\
(p<0.01)\end{array}$ \\
\hline $\begin{array}{l}\text { Komp et al. } \\
\text { [56] }\end{array}$ & 2004 & Prospective & $\| \mathrm{b}$ & non-surgical & 19(19) & $21(21)$ & $\begin{array}{c}6 \\
\text { months }\end{array}$ & $\begin{array}{l}\text { Improvement of VAS and ODI with } \\
\text { kyophoplasty }(p<0.01)\end{array}$ \\
\hline $\begin{array}{l}\text { Kasperk et al } \\
\text { [57] }\end{array}$ & 2005 & Prospective & $\| \mathrm{b}$ & non-surgical & $20(33)$ & $40(72)$ & $\begin{array}{c}12 \\
\text { months }\end{array}$ & $\begin{array}{l}\text { Improvement of VAS }(p<0.01) \text { and } \\
\text { improvement of kyphosis }(p<0.001) \text { with } \\
\text { kyphoplasty }\end{array}$ \\
\hline $\begin{array}{l}\text { Grohs et al. } \\
{[58]}\end{array}$ & 2005 & Prospective & $11 \mathrm{~b}$ & vertebroplasty & $23(29)$ & $28(35)$ & $\begin{array}{c}24 \\
\text { months }\end{array}$ & $\begin{array}{l}\text { No significant difference in ODI, but } \\
\text { improvement of VAS with kyphoplasty } \\
(p<0.05) \text {. No significant improvement of kyphosis }\end{array}$ \\
\hline $\begin{array}{l}\text { Masala et al. } \\
{[59]}\end{array}$ & 2005 & Retrospective & $\| l \mid b$ & vertebroplasty & $26(33)$ & $7(7)$ & $\begin{array}{c}6 \\
\text { months }\end{array}$ & No significant difference in VAS. \\
\hline $\begin{array}{l}\text { Pflugmacher } \\
\text { et al [30] }\end{array}$ & 2005 & Prospective & $\| b$ & vertebroplasty & $20(32)$ & $22(35)$ & $\begin{array}{c}12 \\
\text { months }\end{array}$ & $\begin{array}{l}\text { No significant difference in VAS and ODI. } \\
\text { Improvement of kyphosis with kyphoplasty } \\
(p<0.05)\end{array}$ \\
\hline $\begin{array}{l}\text { De Negri et } \\
\text { al. [60] }\end{array}$ & 2007 & Prospective & $\| \mathrm{b}$ & vertebroplasty & $10(18)$ & $11(15)$ & $\begin{array}{c}6 \\
\text { months }\end{array}$ & No significant difference in VAS and ODI. \\
\hline $\begin{array}{l}\text { Zhou et al. } \\
\text { [61] }\end{array}$ & 2008 & Prospective & IIIb & vertebroplasty & 42 & 56 & $\begin{array}{c}12 \\
\text { months }\end{array}$ & $\begin{array}{l}\text { No significant differences in VAS, operation time } \\
\text { and blood loss. Improved vertebral height } \\
\text { restoration with kyphoplasty }(p<0.01) \text {. }\end{array}$ \\
\hline $\begin{array}{l}\text { Wardlaw et } \\
\text { al. [13] }\end{array}$ & 2009 & Randomised & $\mathrm{lb}$ & non-surgical & 149 & 151 & $\begin{array}{c}12 \\
\text { months }\end{array}$ & $\begin{array}{l}\text { Significant improvement in EQ-5D }(p<0.05) \\
\text { RMDQ }(p<0.001) \text { VAS }(p<0.0001)\end{array}$ \\
\hline $\begin{array}{l}\text { Schmelzer- } \\
\text { Schmied et } \\
\text { al. [51] }\end{array}$ & 2009 & Prospective & $\| b$ & non-surgical & 20 & 20 & $\begin{array}{c}12 \\
\text { months }\end{array}$ & $\begin{array}{l}\text { Significant greater improvement of VAS } \\
(p<0.05) \text { with kyphoplasty, which was lost after } \\
3 \text { months, and vertebral height preservation } \\
\text { after } 12 \text { months }(p<0.01)\end{array}$ \\
\hline $\begin{array}{l}\text { Schofer et al. } \\
\text { [62] }\end{array}$ & 2009 & Prospective & IIIb & vertebroplasty & 30 & 30 & $\begin{array}{c}13 \\
\text { months }\end{array}$ & $\begin{array}{l}\text { No significant differences in VAS and SF-36. } \\
\text { Greater improvement of kyphotic angle with } \\
\text { kyphoplasty }(p<0.001)\end{array}$ \\
\hline $\begin{array}{l}\text { Li X et al } \\
{[63]}\end{array}$ & 2011 & Prospective & IIlb & vertebroplasty & 40 & 45 & $\begin{array}{c}12 \\
\text { months }\end{array}$ & $\begin{array}{l}\text { No significant differences in VAS and ODI. } \\
\text { Significantly greater improvement of kyphotic } \\
\text { angle with kyphoplasty }(p<0.01)\end{array}$ \\
\hline
\end{tabular}


systemic toxic monomers, osteoinductive capacity, and close to isothermal cristallinisation. Disadvantages are besides less clinical long-term experience, lesser compressive strength than PMMA [47], and the risk of early resorption, leading to defects prone to re-fractures [48-50]. The available data does not encourage the clinical use of $\mathrm{CaP}$-cement in burst-fractures, flexion-distraction injuries, or rotational instable fractures $[48,51]$.

\section{Results and complications of kyphoplasty}

Fourteen years after the first vertebroplasty was performed in 1984, balloon kyphoplasty challenged the conventional augmentation procedures promising less complications and sagittal reconstructive ability. Until now several non-randomized prospective controlled trials have been published comparing kyphoplasty to non-surgical treatment and vertebroplasty (Table 2). Besides pain improvement and quality of life, correction of deformity and intra- and postoperative complications were investigated. The recently presented preliminary 1year-results of the multicentrical randomized controlled Fracture Reduction Evaluation (FREE) study present in the kyphoplasty group a significant improvement of the quality of life (EQ-5D (EuroQoL), $\mathrm{p}<0.001$ ), pain (VAS, $\mathrm{p}<0.0001$ ), and function (SF-36 (Short form Health Survey), $\mathrm{p}<0.0001$, ODI, $\mathrm{p}<0.0001$ ) after 1 month ( $\mathrm{n}$ = 149) controlled against non-surgical treatment $(\mathrm{n}=$ 151) [13]. These treatment-effects diminished dramatically until the 12-month follow-up, but were still significantly better than non-surgical treatment for quality of life as measured with EQ-5D ( $\mathrm{p}<0.05)$.

The comprehensive meta-analysis of Lee et al [52] summarized all published kyphoplasty complications. Cement leakages occurred in $14 \%$ of all cases, but only $0.01 \%$ were symptomatic. New vertebral fractures occurred in $17 \%$. Taylor et al [53] found in their metaanalysis furthermore spinal stenosis with spinal cord compression occurred $0.16 \%$ of all cases. Radiculopathy was found in $0.17 \%$ of all cases. Furthermore there are anecdotal reports of infections after kyphoplasty [26]. The overall mortality was $4.4 \%$, and the perioperative mortality was $0.13 \%$ [53].

\section{Conclusions}

Kyphoplasty is - in the hands of an experienced spine surgeon or radiological interventionalist - an effective tool to treat pain caused by thoracolumbar vertebral compression fractures, but the severity of pulmonary PMMA cement embolism and the urgent need of immediate decompression in relevant spinal stenosis after cement leakage, require an anaesthesiologist and a spinal surgeon on call. The complication rate of kyphoplasty is dramatically lower than in alternative open instrumented procedures, and the immediate pain reduction is significantly greater in kyphoplasty compared to conservative treatment. Therefore its application remains a pillar in VCF treatment.

\section{Author details}

${ }^{1}$ Uppsala University Hospital, Institute for Surgical Sciences, Department of Orthopaedics, Uppsala, Sweden. 'Leipzig University Hospital, Department of Orthopaedic Surgery, Spine Surgery, Leipzig, Germany.

\section{Authors' contributions}

YR wrote the manuscript, and CEH, PF and CO revised it critically. All authors read and approved the final manuscript.

\section{Competing interests}

YR, CEH, and PF were clinical investigators in the FREE trial, and YR and PF were Clinical Investigators in the CAFE trial, both initiated by Kyphon Inc. (now Medtronic Spine LLC, Sunnyvale, CA, USA). YR, CEH, PF and CO received travel assistance by Medtronic, DePuy Spine (Johnson \& Johnson) and Synthes

Received: 5 February 2011 Accepted: 19 August 2011 Published: 19 August 2011

\section{References}

1. Felsenberg D, Silman AJ, Lunt M, Armbrecht G, Ismail AA, Finn JD, Cockerill WC, Banzer D, Benevolenskaya LI, Bhalla A, et al: Incidence of vertebral fracture in europe: results from the European Prospective Osteoporosis Study (EPOS). J Bone Miner Res 2002, 17:716-724.

2. Lad SP, Patil CG, Lad EM, Boakye M: Trends in pathological vertebral fractures in the United States: 1993 to 2004. J Neurosurg Spine 2007 7:305-310.

3. Pluijm SM, Tromp AM, Smit JH, Deeg DJ, Lips P: Consequences of vertebral deformities in older men and women. J Bone Miner Res 2000, 15:1564-1572.

4. Gold DT: The clinical impact of vertebral fractures: quality of life in women with osteoporosis. Bone 1996, 18:185S-189S.

5. Center JR, Nguyen TV, Schneider D, Sambrook PN, Eisman JA: Mortality after all major types of osteoporotic fracture in men and women: an observational study. Lancet 1999, 353:878-882.

6. Rohlmann A, Klockner C, Bergmann G: [The biomechanics of kyphosis]. Orthopade 2001, 30:915-918.

7. Schwab F, Lafage V, Patel A, Farcy JP: Sagittal plane considerations and the pelvis in the adult patient. Spine (Phila Pa 1976) 2009, 34:1828-1833.

8. Galibert P, Deramond H, Rosat P, Le Gars D: [Preliminary note on the treatment of vertebral angioma by percutaneous acrylic vertebroplasty]. Neurochirurgie 1987, 33:166-168.

9. Deramond H, Depriester C, Galibert P, Le Gars D: Percutaneous vertebroplasty with polymethylmethacrylate. Technique, indications, and results. Radiol Clin North Am 1998, 36:533-546.

10. Lee JS, Kim KW, Ha KY: The Effect of Vertebroplasty on Pulmonary Function in Patients With Osteoporotic Compression Fractures of the Thoracic Spine. J Spinal Disord Tech .

11. Voggenreiter G: Balloon kyphoplasty is effective in deformity correction of osteoporotic vertebral compression fractures. Spine (Phila Pa 1976) 2005, 30:2806-2812.

12. Luo J, Bertram W, Sangar D, Adams MA, Annesley-Williams DJ, Dolan P: Is kyphoplasty better than vertebroplasty in restoring normal mechanical function to an injured spine? Bone 46:1050-1057.

13. Wardlaw D, Cummings SR, Van Meirhaeghe J, Bastian L, Tillman JB, Ranstam J, Eastell R, Shabe P, Talmadge K, Boonen S: Efficacy and safety of balloon kyphoplasty compared with non-surgical care for vertebral compression fracture (FREE): a randomised controlled trial. Lancet 2009, 373:1016-1024.

14. Buchbinder R, Osborne RH, Ebeling PR, Wark JD, Mitchell P, Wriedt C, Graves S, Staples MP, Murphy B: A randomized trial of vertebroplasty for painful osteoporotic vertebral fractures. N Engl J Med 2009, 361:557-568.

15. Kallmes DF, Comstock BA, Heagerty PJ, Turner JA, Wilson DJ, Diamond TH, Edwards R, Gray LA, Stout L, Owen S, et al: A randomized trial of 
vertebroplasty for osteoporotic spinal fractures. N Engl J Med 2009, 361:569-579.

16. Rousing R, Andersen MO, Jespersen SM, Thomsen K, Lauritsen J: Percutaneous vertebroplasty compared to conservative treatment in patients with painful acute or subacute osteoporotic vertebral fractures: three-months follow-up in a clinical randomized study. Spine (Phila Pa 1976) 2009, 34:1349-1354

17. Fisher CG, Vaccaro AR: The highest level of evidence in a high impact journal: is this the final verdict? Spine (Phila Pa 1976) 35:E676-677.

18. Karlsson MK, Ohlin A, Hasserius R: Could vertebroplasty and kyphoplasty be regarded as evidence-based treatment of osteoporotic vertebral fractures? Acta Radiol 51:828-831.

19. Hasserius R, Ohlin A, Karlsson MK: Vertebroplasty and kyphoplastyevidence-based methods? Acta Orthop 81:521-523.

20. Miller FG, Kallmes DF: The case of vertebroplasty trials: promoting a culture of evidence-based procedural medicine. Spine (Phila Pa 1976) 35:2023-2026.

21. Heini PF: [Vertebroplasty: an update: value of percutaneous cement augmentation after randomized, placebo-controlled trials]. Orthopade 39:658-664.

22. Flors L, Lonjedo E, Leiva-Salinas C, Marti-Bonmati L, Martinez-Rodrigo JJ, Lopez-Perez E, Figueres G, Raoli I: Vesselplasty: a new technical approach to treat symptomatic vertebral compression fractures. AJR Am J Roentgenol 2009, 193:218-226.

23. Xiong J, Dang Y, Jiang BG, Fu ZG, Zhang DY: Treatment of osteoporotic compression fracture of thoracic/lumbar vertebrae by kyphoplasty with SKY bone expander system. Chin I Traumatol 13:270-274.

24. Renner $\mathrm{S}$ : Restoration of intervertebral disc mechanics after endplate deformity reduction using structural kyphoplasty. J Neurolntervent Surg 2009, 1:76

25. Stoffel M, Wolf I, Ringel F, Stuer C, Urbach H, Meyer B: Treatment of painful osteoporotic compression and burst fractures using kyphoplasty: a prospective observational design. J Neurosurg Spine 2007, 6:313-319.

26. Robinson Y, Tschoke SK, Stahel PF, Kayser R, Heyde CE: Complications and safety aspects of kyphoplasty for osteoporotic vertebral fractures: a prospective follow-up study in 102 consecutive patients. Patient Saf Surg 2008, 2:2.

27. Patel AA, Vaccaro AR, Martyak GG, Harrop JS, Albert TJ, Ludwig SC, Youssef JA, Gelb DE, Mathews HH, Chapman JR, et al: Neurologic deficit following percutaneous vertebral stabilization. Spine (Phila Pa 1976) 2007, 32:1728-1734.

28. Noldge G, DaFonseca K, Grafe I, Libicher M, Hillmeier J, Meeder PJ, Kauffmann GW, Kasperk C: [Balloon kyphoplasty in the treatment of back pain]. Radiologe 2006, 46:506-512.

29. Verlaan JJ, Dhert WJ, Verbout AJ, Oner FC: Balloon vertebroplasty in combination with pedicle screw instrumentation: a novel technique to treat thoracic and lumbar burst fractures. Spine (Phila Pa 1976) 2005, 30: E73-79.

30. Pflugmacher R, Kandziora F, Schroder R, Schleicher P, Scholz M, Schnake K, Haas N, Khodadadyan-Klostermann C: [Vertebroplasty and kyphoplasty in osteoporotic fractures of vertebral bodies - a prospective 1-year followup analysis]. Rofo 2005, 177:1670-1676.

31. Aydogan M, Ozturk C, Karatoprak O, Tezer M, Aksu N, Hamzaoglu A: The pedicle screw fixation with vertebroplasty augmentation in the surgical treatment of the severe osteoporotic spines. J Spinal Disord Tech 2009, 22:444-447.

32. Hato T, Kawahara N, Tomita K, Murakami H, Akamaru T, Tawara D, Sakamoto J, Oda J, Tanaka S: Finite-element analysis on closing-opening correction osteotomy for angular kyphosis of osteoporotic vertebral fractures. J Orthop Sci 2007, 12:354-360.

33. Daubs MD, Lenke LG, Cheh G, Stobbs G, Bridwell KH: Adult spinal deformity surgery: complications and outcomes in patients over age 60 . Spine (Phila Pa 1976) 2007, 32:2238-2244.

34. DeWald CJ, Stanley T: Instrumentation-related complications of multilevel fusions for adult spinal deformity patients over age 65: surgical considerations and treatment options in patients with poor bone quality. Spine (Phila Pa 1976) 2006, 31:S144-151.

35. Cho KJ, Bridwell KH, Lenke LG, Berra A, Baldus C: Comparison of SmithPetersen versus pedicle subtraction osteotomy for the correction of fixed sagittal imbalance. Spine (Phila Pa 1976) 2005, 30:2030-2037, discussion 2038.
36. Kim YJ, Bridwell KH, Lenke LG, Cheh G, Baldus C: Results of lumbar pedicle subtraction osteotomies for fixed sagittal imbalance: a minimum 5-year follow-up study. Spine (Phila Pa 1976) 2007, 32:2189-2197.

37. Boszczyk BM, Bierschneider M, Hauck S, Beisse R, Potulski M, Jaksche H: Transcostovertebral kyphoplasty of the mid and high thoracic spine. Eur Spine J 2005, 14:992-999.

38. Ryu KS, Park CK, Kim MK, Kim DH: Single balloon kyphoplasty using farlateral extrapedicular approach: technical note and preliminary results. J Spinal Disord Tech 2007, 20:392-398.

39. Boszczyk BM, Bierschneider M, Schmid K, Grillhosl A, Robert B, Jaksche H: Microsurgical interlaminary vertebro- and kyphoplasty for severe osteoporotic fractures. J Neurosurg 2004, 100:32-37.

40. Boszczyk B, Bierschneider M, Potulski M, Robert B, Vastmans J, Jaksche H: [Extended kyphoplasty indications for stabilization of osteoporotic vertebral compression fractures]. Unfallchirurg 2002, 105:952-957.

41. Cagli S, Isik HS, Zileli M: Vertebroplasty and kyphoplasty under local anesthesia: review of 91 patients. Turk Neurosurg 20:464-469.

42. Cawley DT, Sexton P, Murphy T, McCabe JP: Optimal patient positioning for ligamentotaxis during balloon kyphoplasty of the thoracolumbar and lumbar spine. J Clin Neurosci

43. Choi HC: Fluoroscopic Radiation Exposure during Percutaneous Kyphoplasty. J Korean Neurosurg Soc 49:37-42.

44. Kang JD, An H, Boden S, Phillips F, Foley K, Abdu W: Cement augmentation of osteoporotic compression fractures and intraoperative navigation: summary statement. Spine (Phila Pa 1976) 2003, 28:S62-63.

45. Ohnsorge JA, Siebert CH, Schkommodau E, Mahnken AH, Prescher A, Weisskopf M: [Minimally-invasive computer-assisted fluoroscopic navigation for kyphoplasty]. Z Orthop Ihre Grenzgeb 2005, 143:195-203.

46. Greene DL, Isaac R, Neuwirth M, Bitan FD: The eggshell technique for prevention of cement leakage during kyphoplasty. J Spinal Disord Tech 2007, 20:229-232.

47. Wilke HJ, Mehnert U, Claes LE, Bierschneider MM, Jaksche H, Boszczyk BM: Biomechanical evaluation of vertebroplasty and kyphoplasty with polymethyl methacrylate or calcium phosphate cement under cyclic loading. Spine (Phila Pa 1976) 2006, 31:2934-2941.

48. Blattert TR, Jestaedt L, Weckbach A: Suitability of a calcium phosphate cement in osteoporotic vertebral body fracture augmentation: a controlled, randomized, clinical trial of balloon kyphoplasty comparing calcium phosphate versus polymethylmethacrylate. Spine (Phila Pa 1976) 2009, 34:108-114.

49. Heo HD, Cho YJ, Sheen SH, Kuh SU, Cho SM, Oh SM: Morphological changes of injected calcium phosphate cement in osteoporotic compressed vertebral bodies. Osteoporos Int 2009, 20:2063-2070.

50. Heo DH, Chin DK, Yoon YS, Kuh SU: Recollapse of previous vertebral compression fracture after percutaneous vertebroplasty. Osteoporos Int 2009, 20:473-480.

51. Schmelzer-Schmied N, Cartens C, Meeder PJ, Dafonseca K: Comparison of kyphoplasty with use of a calcium phosphate cement and nonoperative therapy in patients with traumatic non-osteoporotic vertebral fractures. Eur Spine J 2009, 18:624-629.

52. Lee MJ, Dumonski M, Cahill P, Stanley T, Park D, Singh K: Percutaneous treatment of vertebral compression fractures: a meta-analysis of complications. Spine (Phila Pa 1976) 2009, 34:1228-1232.

53. Taylor RS, Fritzell P, Taylor RJ: Balloon kyphoplasty in the management of vertebral compression fractures: an updated systematic review and meta-analysis. Eur Spine J 2007, 16:1085-1100.

54. Weisskopf M, Herlein S, Birnbaum K, Siebert C, Stanzel S, Wirtz DC: [Kyphoplasty - a new minimally invasive treatment for repositioning and stabilising vertebral bodies]. Z Orthop Ihre Grenzgeb 2003, 141:406-411.

55. Fourney DR, Schomer DF, Nader R, Chlan-Fourney J, Suki D, Ahrar K, Rhines LD, Gokaslan ZL: Percutaneous vertebroplasty and kyphoplasty for painful vertebral body fractures in cancer patients. J Neurosurg 2003, 98:21-30.

56. Komp M, Ruetten S, Godolias G: [Minimally-invasive therapy for functionally unstable osteoporotic vertebral fractures by means of kyphoplasty: prospective comparative study of 19 surgically and 17 conservatively treated patients.]. J Miner Stoffwechs 2004, 11:604-612.

57. Kasperk C, Hillmeier J, Noldge G, Grafe IA, Dafonseca K, Raupp D, Bardenheuer H, Libicher M, Liegibel UM, Sommer U, et al: Treatment of painful vertebral fractures by kyphoplasty in patients with primary 
osteoporosis: a prospective nonrandomized controlled study. J Bone Miner Res 2005, 20:604-612.

58. Grohs JG, Matzner M, Trieb K, Krepler P: Minimal invasive stabilization of osteoporotic vertebral fractures: a prospective nonrandomized comparison of vertebroplasty and balloon kyphoplasty. J Spinal Disord Tech 2005, 18:238-242.

59. Masala S, Lunardi P, Fiori R, Liccardo G, Massari F, Ursone A, Simonetti G: Vertebroplasty and kyphoplasty in the treatment of malignant vertebral fractures. J Chemother 2004, 16(Suppl 5):30-33.

60. De Negri P, Tirri T, Paternoster G, Modano P: Treatment of painful osteoporotic or traumatic vertebral compression fractures by percutaneous vertebral augmentation procedures: a nonrandomized comparison between vertebroplasty and kyphoplasty. Clin J Pain 2007, 23:425-430.

61. Zhou JL, Liu SQ, Ming JH, Peng H, Qiu B: Comparison of therapeutic effect between percutaneous vertebroplasty and kyphoplasty on vertebral compression fracture. Chin J Traumatol 2008, 11:42-44.

62. Schofer MD, Efe T, Timmesfeld N, Kortmann HR, Quante M: Comparison of kyphoplasty and vertebroplasty in the treatment of fresh vertebral compression fractures. Arch Orthop Trauma Surg 2009, 129:1391-1399.

63. Li X, Yang H, Tang T, Qian Z, Chen L, Zhang Z: Comparison of Kyphoplasty and Vertebroplasty for Treatment of Painful Osteoporotic Vertebral Compression Fractures: Twelve-month Follow-up in a Prospective Nonrandomized Comparative Study. J Spinal Disord Tech

doi:10.1186/1749-799X-6-43

Cite this article as: Robinson et al: Kyphoplasty in osteoporotic vertebral compression fractures - Guidelines and technical considerations. Journal of Orthopaedic Surgery and Research 2011 6:43.

\section{Submit your next manuscript to BioMed Central and take full advantage of:}

- Convenient online submission

- Thorough peer review

- No space constraints or color figure charges

- Immediate publication on acceptance

- Inclusion in PubMed, CAS, Scopus and Google Scholar

- Research which is freely available for redistribution

Submit your manuscript at www.biomedcentral.com/submit
Biomed Central 